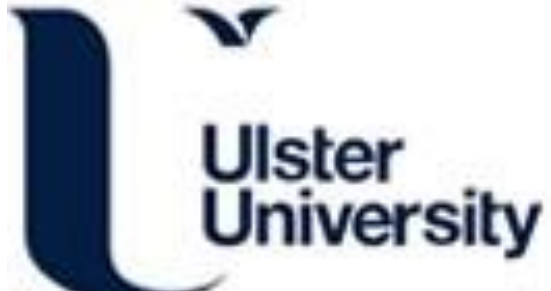

\section{The Engage programme and the Government Communication Network in the UK, 2006-2010}

Ramsey, P. (2015). The Engage programme and the Government Communication Network in the UK, 2006-2010. Journal of Public Affairs, 15(4), 377-386. https://doi.org/10.1002/pa.1550

Link to publication record in Ulster University Research Portal

\section{Published in:}

Journal of Public Affairs

Publication Status:

Published (in print/issue): 03/11/2015

DOI:

10.1002/pa.1550

\section{Document Version}

Author Accepted version

\section{General rights}

Copyright for the publications made accessible via Ulster University's Research Portal is retained by the author(s) and / or other copyright owners and it is a condition of accessing these publications that users recognise and abide by the legal requirements associated with these rights.

\section{Take down policy}

The Research Portal is Ulster University's institutional repository that provides access to Ulster's research outputs. Every effort has been made to ensure that content in the Research Portal does not infringe any person's rights, or applicable UK laws. If you discover content in the Research Portal that you believe breaches copyright or violates any law, please contact pure-support@ulster.ac.uk. 
The Engage programme and the Government Communication Network in the UK, 2006-2010

Phil Ramsey, Ulster University

pt.ramsey@ulster.ac.uk

http://ulster.academia.edu/PhilRamsey | http://orcid.org/0000-0001-5873-489X

This is the peer reviewed version of the following article:

Ramsey, P. (2015). The Engage programme and the Government Communication Network in the UK, 2006-2010. Journal of Public Affairs. 15(4): 377-386, which has been published in final form at http://dx.doi.org/10.1002/pa.1550.

This article may be used for non-commercial purposes in accordance with Wiley Terms and Conditions for Self-Archiving: http://olabout.wiley.com/WileyCDA/Section/id-828039.html\#terms

\begin{abstract}
The Engage programme was launched in April 2006 by the Government Communication Network (GCN) in the UK. As a civil service body supporting those in government working as press officers and in marketing roles, the GCN under the New Labour government in the period 2006-2010 was involved with the extension of the logic of marketisation to government communication. This article charts this process by examining key government policy documents from this period. The rationale for Engage rested on the assumption that government in the UK needed to adapt its communication approach to reach what were perceived as individualised consumers in society. The extension of the logic of marketisation to government communication that happened under Engage is shown to be consistent with the New Public Management approach to public services under New Labour.
\end{abstract}

Keywords: government communication; New Labour; Government Communication Network; new public management; marketisation. 


\section{The Engage programme and the Government Communication Network in the UK, 2006-2010}

\section{Introduction}

The Engage programme was launched in April 2006 by the Government Communication Network (GCN) under the New Labour government (1997-2010). As a civil service body in the UK, supporting government press officers and those working in marketing, the GCN contributed to the extension of the logic of marketisation to government communication. Under the terms of Engage, the 'public' were conceived of as an 'audience', while 'citizens' were conceived of as 'consumers'. This article charts this shift by surveying several key government policy documents that helped shape Engage and changed the terms of government communication in the period 2006-2010. The establishment of the post of 'Permanent Secretary, Government Communications' under New Labour and the resulting innovations that were put in place, led to a breaking down of the traditional dichotomy between news and information, and advertising and marketing. The first person to hold the position was Howell James, who argued that under the terms of communication government should be considered as a company and citizens as consumers. This position was intellectually consistent with the idea shown in Engage documentation, that some sort of fundamental societal shift had occurred by 2006, rendering traditional government communication approaches redundant. The rationale for Engage rests on the assumption that government in the UK at this time needed to adapt its approach to communication to reach what were perceived as individualised consumers in society. This article locates this in relation to the New Public Management (NPM) approach to public services under New Labour, as influenced by public choice theory.

The article is comprised of desk-based research, employing documentary analysis to provide a qualitative analysis of UK government policy documents. It draws on archival research techniques, used to retrieve policy documents from online databases, and other government information placed online (Atkinson and Coffey, 2004). These policy documents (and Internet sources) come both from the direct period of analysis (2006-2010) and from the wider period of 1997-2011, in order to highlight the policy context under New Labour before the Engage programme was launched, and in the period that immediately followed the cessation of the New Labour government. The documents analysed include ten from the Cabinet Office (the ministerial department that coordinates the work of government in the UK), one from the Central Office of Information, and five that emanated directly from central government. Two speeches from a senior civil servant (Howell James) are considered alongside material from two UK Parliamentary select committees: the House of Lords Select Committee on Communications and the House of Commons Select Committee on Public Administration. The documentary analysis approach that is employed in this article was guided by the following points, to ensure that the following was considered: 1) the information that the given document provides on the Engage programme, and its position within the overall framework for government communication during this period; 2) the information that the given document provides on Engage in relation to the extension of the logic of marketisation to government communication, where changes have taken place as compared to former structures; 3) the information that the given document provides on how Engage was connected to the wider political principles underpinning New Labour, both as a government and as a political project. 


\section{New Labour and Government Communication}

The charge that New Labour had ushered a new era of 'spin' in government communication into British political life, that superseded anything that had gone before, was heard from many quarters. It can be suggested that New Labour became synonymous with spin, and the party experienced a substantial breakdown in trust regarding its communication style (see Cabinet Office, 2004). Numerous studies have addressed the extent to which spin was practiced by New Labour in its government communication and have attempted to provide a theorisation of the practice (Andrews, 2006; Franklin, 2004a, 2004b; Gaber, 2000a, 2000b; McNair, 2000, 2004). Given the extent of the problem, other scholars have discussed the regulation of government communication and the extent to which spin might be limited (Daintith, 2001; Yeung, 2006). Various events relating to communication during the New Labour years resulted in inquiries and government reviews, such as the report of the House of Commons Public Administration Select Committee report (2002) that followed the furore over actions at the Department of Transport, Local Government and the Regions. There a special advisor sent an email on 11 September 2001, "urging the release of "anything we want to bury" in the aftermath of the terrorist attacks on the USA' (House of Commons Public Administration Select Committee, 2002: 5). That report called for 'a sustainable improvement in the quality of the service provided by the permanent civil servants in the Government Information and Communication Service' (Cabinet Office, 2004: 1).

The recommendation of the Public Administration Select Committee led to the Phillis Review, and the resulting report has a substantial bearing on the content of this article. Gaber (2004: 366) argues that as two reports were published - an interim and final report - the impact of the review was muted: 'Its significance has been confused in the public discussion because, amid the protracted resignation process, two reports from an independent inquiry into government communications were published', with the first being published four days after Alastair Campbell's resignation, and the second being published four days before the Hutton Inquiry reported. Returning to the ramifications of Phillis in media and communication research in the UK is of central importance; it remains a critical starting point for judging later government policy, such as the Engage programme. In his report, Phillis found that there had been 'A three way breakdown in trust between politicians, media and the public', and that there should 'be a sustained commitment to a long-term programme of radical change in the conduct, process and style of government communications' (Cabinet Office, 2004: 2). Phillis also found that the 'credibility' of government communications needed to be restored following various events regarding government communication since 1997. The principles the report sets out encourage a move towards greater openness and transparency in government communication, and a move towards greater unmediated communication between politicians and the public. Specifically, the Phillis review found that the Civil Service communication model was outdated, and that the Civil Service had 'not grasped the potential of modern communications as a service provided for citizens' (Cabinet Office, 2004: 3). Phillis argued that the then incumbent Government Information Communication Service (GICS) was not fit for purpose, and recommended its dissolution. The new communications service that was set up was the aforementioned GCN, that replaced the GICS in late 2004.

\section{The Post-Phillis environment in Government Communication}

Of the twelve recommendations that Phillis made, two points are of particular importance to this analysis. First, on the Civil Service communication structure, Phillis recommended the installation of a new 'Permanent Secretary, Government 
Communications', to provide improved structure, and greater accountability (Cabinet Office, 2004: 2). As 'Head of Profession' he or she would have a remit to 'provide strategic leadership for communications across government' (Cabinet Office, 2004: 2). Part of the rationale behind the establishment of the role of Permanent Secretary, Government Communications, was that the occupier of the role might become an assessor and appraiser of government communication, while also being in charge of it. Phillis suggested that this would be one way of ensuring 'consistency and high standards across government', and that the Permanent Secretary would 'provide the framework against which departments assess their communications performance' (Cabinet Office, 2004: 14). Howell James was the first incumbent of the position, and was later replaced by Matt Tee in November 2008 (HM Government, 2008). The Permanent Secretary position was located within the Cabinet Office, directly responsible to Sir Gus O'Donnell, the then Cabinet Secretary and head of the Civil Service (this post has subsequently been divided between different role holders).

One of the key shifts that occurred in the post-Phillis environment of government communication was the merging of government communication relating to news and information with what could be termed advertising and marketing. Under the pre-Phillis arrangements there was a wider gap between the work of the Government Information Service (GIS), that became the GICS, and the work of the Central Office for Information (COI), which was termed the 'Government's centre of excellence for marketing and communications' (COI, 2010). In the case of the GIS and the GICS, the emphasis was on news and information, while the COI had an emphasis on direct advertising. This was despite the fact that Alastair Campbell (the Director of Communications and Strategy under Tony Blair) had held formal control over both since 2002 (Weir, 2002). Under the Phillis arrangements - namely the instituting of the post of Permanent Secretary, Government Communications - the dichotomy between these two areas became less clear. Indeed, the first incumbent of the new post Howell James (2005a) stated that 'unlike the GICS, [the GCN] ... will support and connect all government communicators - from those working in internal, stakeholder and ecommunication to those that are marketing specialists and press officers'. This shift is crucial to the terms of analysis of this article, whereby government communication pertaining to news management and political communication to journalists became increasingly merged with a more marketised model of communication relating to direct communications to citizens, whereby some functions of government communication are moved into the private sector, while the main shift is through the extension of market logic to government communication. The post of Permanent Secretary, Government Communications formalised the connections between these two areas, in a way that had not previously been the case. The closing down of the COI was later recommended by Matt Tee (Cabinet Office, 2011), with the decision being implemented in 2012.

\section{Government Communication: 'akin to the role of marketing in a successful company'}

To begin to understand the extent to which the principles of marketing were brought into government communication under New Labour, we can turn to two speeches from Howell James (the first holder of the Permanent Secretary, Government Communications post). In What future for Government Communications? James (2005a) noted that he understood his role as making 'the voice of the public heard at the policy table so that government develops and delivers services which reflect customer expectations and desires'. In a separate speech given the same year, Lemons into Peaches (1), James set out his perspective that the basic work of government 
communication was managing the flow of news (James, 2005b). He outlined the threat of a breakdown in trust between government and the public, where there is a 'perceived asymmetry of information between government and public' (James, 2005b). However, he argued most prominently in the speech that government communication should be located firmly within a business paradigm, with citizens being primarily viewed as consumers. James argued that communication in government is 'akin to the role of marketing in a successful company. Whenever I say that in front of audiences like this, I see sceptical eyebrows being raised. But I believe it's true' (James, 2005b). His argument followed from the view that in successful companies marketers listen to the needs and wants of the customers, and begin to reflect this in their products, 'so that the fit between product and need becomes ever closer and most satisfying' (James, 2005b).

Reverting to the first mentioned speech, government communication for James should learn directly from private sector approaches: 'I want to see government communicators able to learn from the best and most customer driven approaches in the private sector and adapt these disciplines to the unique circumstances of government' (James, 2005a). As government communication begins to replicate good business practice, and operate accordingly, the public become the 'market' and the government the 'marketers'. This argument is crystallised in this passage from Lemons into Peaches:

Effective government communication means rebuilding chunks of the machinery of government around the disciplines of marketing ... That means getting close to the public. Indeed it means bringing the public into government. It's about developing acutely-sensitive antennae, about listening hard, about sharing information, about involving the public in policy-development, and continuously and explicitly refining policy and policy-delivery in response to their concerns. (James, 2005b)

In James's understanding, government communication is most effective when based around marketing principles, where the view of the customer is of primary importance. This is a movement away from communication models where the citizen requires information from government, which leads to the formation of public opinion and ultimately impacts on the voting process (Habermas, 2009). While in this passage James allows for the 'bringing the public into government', it is done so under the logic of market principles, rather than the principles of citizenship.

\section{The Engage programme}

In April 2006 the GCN established the Engage programme, as 'a strategic framework for government communication' (Cabinet Office, 2006a). Howell James stated that this would 'address the issue in Phillis about those various behaviours between departments' to bring about 'a more professional communications function across the piece' (House of Lords Select Committee on Communications, 2009: 17-18). The government suggested that Engage was 'about putting the public at the heart of government communications in line with the Phillis report' (HM Government, 2009), while the Cabinet Office (2006b) specifically noted 'the Engage programme came into being, to help government communicators understand the implications of changing audience behaviour'. The government stated that Engage takes 'well tried principles of strategic communication and adapts them for government' (HM Government, 2007). During the period of analysis, Engage was governed by eight principles, that included 'listening ... to people's motivations, needs and barriers' and 'Reaching people in complex communications environments' (Cabinet Office, 2006c). In practical terms, Engage was 
resourced in government with:

a knowledge bank, providing you with a practical set of principles, tools, case studies and training materials to create engaging communication; a programme of events, training and development courses to help you put these materials into action; a leadership and engagement programme, providing a context where government communications can adapt and develop to put the public at the heart of policy. (Cabinet Office, 2006a)

While this article only considers Engage policy materials up until 2010 (the end point of the New Labour government), the programme did survive beyond this point for just under three years. Engage was later replaced by the Government Communication Professional Competency Framework, a framework grouped around four themes: insight, ideas, implementation, impact (GCN, 2013a: 3), with these remaining similar to the Engage principles. What was confirmed, however, was the extent to which integration between professional roles in government communication was present, with the GCN stating: 'if you work in a press office, we expect you to get better at digital. If you work in digital, we expect you to become better at developing and running integrated campaigns' (GCN, 2013b).

\section{From 'Public' to 'Audience', from 'Citizen' to 'Customer'}

The presence of the term 'audience' rather than 'public' is fairly consistent throughout Engage policy documentation, although not ubiquitous (Cabinet Office, 2005, 2006b, 2007). The term has a central place in one of the main Cabinet Office descriptions of Engage: 'Engage is a way of making government communications more effective by putting our audiences first. At its heart is a simple truth: great communication starts with an open mind and a listening ear' (Cabinet Office, 2006a). While this study does not employ a formal discourse analysis approach, the use of terminology is important here with respect to what it suggests about policy, and the wider ideological approach of the GCN. Engage recommended that government communicators increasingly consider ways in which to tailor their communication to the needs and desires of the audience, conceiving of government as a company trying to sell ideas, in a manner consistent with the Howell James approach discussed above. This is government communication informed from the bottom up, rather than the top down, with government reacting to the whims of the audience in the way that, for example, a commercial television company is by necessity required to respond to the whim of the market. In a separate source, the government suggested:

The drive behind the Engage programme is to focus on the needs of citizens in order to deliver policies and services that meet them more fully. Innovative tools such as insight generation and journey mapping are now being used widely to inform policy development and improve the total citizen experience. (Cabinet Office, 2009: 125)

Notice that in this passage the term 'citizen' remains, and is not literally replaced by 'customer'. However, theoretically, the approach here replicates the approach shown in various aspects of marketing theory. For example, the inclusion of the terms 'insight generation' and 'journey mapping' provide clear illustration for the point that government is embedding marketing principles into its communication policies. On insight generation, the European Society for Opinion and Market Research (ESOMAR) 
suggests that it is 'a multi-facetted concept, crucial throughout any innovation cycle. Generating insights is a constant stream of learning, interpreting, applying and then going back to learning' (ESOMAR, 2010). The rationale for utilising insight generation is based on an inherent understanding that communication should be constantly informed and re-informed by the receivers of the communication, in this case the public.

On customer journey mapping (CJM), we can turn the government's own definition of the term, contained within Customer Journey Mapping: An Introduction, (written by Oxford Strategic Marketing) (Cabinet Office, 2010). As the title suggests, the term citizen is dropped in favour of 'customer' in this case. The document states: 'Across government there's a growing emphasis on getting closer to customers, in order to design and deliver services that meet the needs of people and businesses rather than the needs of government' (Cabinet Office, 2010). In specifically defining the term CJM, it states that it is 'the process of tracking and describing all the experiences that customers have as they encounter a service ... taking into account not only what happens to them, but also their responses to their experiences' (Cabinet Office, 2010). There is also an emphasis placed on cutting back spending on public services, through references to efficiency saving. It states: 'Journey mapping can deliver a better customer experience and bring about greater efficiencies. More satisfied customers are cheaper to serve and easier to deal with' (Cabinet Office, 2010). It is suggested that CJM helps to identify the "cheapest "cost to serve" (Cabinet Office, 2010); in other words, this is about driving down the cost of communicating to each 'customer'. This shift, encompassing the greater marketisation of government communication, is consistent with the NPM approach to public services that will be discussed in more detail below.

\section{A fundamental shift in the communications environment?}

The documentation attached to the Engage programme suggests that some sort of fundamental societal shift had occurred by this point, thus rendering traditional communication approaches redundant. For example, the policy Making Government work better by...Putting our audiences first (Cabinet Office, 2007) is illuminating as the material relates more so to the kind of government communication that had hitherto been the domain of government advertising, and thus under the remit of the COI and not the GCN (or its predecessors, the GIS or the GICS). The central premise of the document is that government is just one voice among many, vying for the public's attention: 'This explosion of new channels, new media and new ways of communicating demands fresh approaches and tools, and this is what the Engage programme provides' (Cabinet Office, 2007: 42). For the Cabinet Office, marketing techniques should be imported into government communication, in a manner more akin to the COI (as suggested above). Part of this involves 'gaining deep insights into what motivates people. By basing your communication on genuine insight into your audience, real behaviour change can happen' (Cabinet Office, 2007: 42). The extent to which the GCN were adopting both the language and the practices of marketing is clear. This is shown in the types of organisations that lined up to endorse Engage and its practices, including The Chartered Institute of Marketing, the Chartered Institute of Public Relations and the National Social Marketing Centre (Cabinet Office, 2007: 43).

The view that a fundamental societal shift had taken place is also seen clearly in the Cabinet Office document, The communication challenge:

Big changes in our society, and to the media that serves it, are presenting new challenges to those of us who are tasked to communicate in Government. How do we ensure our messages cut through the clutter to reach increasingly cynical 
or indifferent audiences? Clearly, some of our traditional tools aren't working any more. And new situations are demanding new tools. (Cabinet Office, 2009: 125)

Indeed, there have been paradigm shifting changes in the media landscape in the past decade or so, including the introduction of Facebook in 2004, Youtube in 2005 and Twitter in 2006. However, the solution that is offered under Engage is what most particularly needs interrogated. To find a solution to the research question posed in the quotation above ('How do we ensure our messages...?'), the Cabinet Office turned to the private sector, publishing Talking to Me? Connecting with Citizens in the Changing Media Landscape (Cabinet Office, 2005) (2). In the foreword Howell James sets out the 'new mission' for government communication, as being:

to help Government understand and respond to what people want and need and to help people find what they want and need from Government. This will enable us to deliver expert, effective communication and help to ensure the voice of Government is heard. (Cabinet Office, 2005: 3)

The report clearly argues that government communication must adapt its communication to reach the more privatised, individualised citizen in society, and have its agenda set by societal trends. One table in the report shows societal 'trends' and 'counter-trends', which it is argued 'is not contradictory; it is generally a result of the fragmentation of society. In identifying implications, therefore, care has to be taken to avoid a "one size fits all" approach' (Cabinet Office, 2005: 6). Here society is understood as being in flux, with former paradigms of communication being undermined by changes in the age profile and affluence of society.

To return to the previously discussed Engage document (Cabinet Office, 2006b), we learn under the heading The communication landscape that the rationale for the Cabinet Office adopting such a marketised approach in the first instance stems from the Phillis Review: 'It called for, "genuine engagement with the public as part of policy formation and delivery". But how do we do this?' (Cabinet Office, 2006b). While this was indeed one of the findings of Phillis, to move from a review that was instigated in the wake of the indiscretion on the part of a Special Advisor over a news and information matter, to the implementation of a full-scale marketised approach across all government communication is to take a large leap. The communication landscape document states that the Cabinet Office had 'taken advice from top flight communications practitioners in Government and the private sector and adapted the best of their thinking for Government' (Cabinet Office, 2006b), but this is seemingly not what Phillis recommended (3). As stated at the beginning of this section on Engage, the key shift that appears to occur in the post-Phillis environment is the merging of government communication relating to news and information, with what could be termed government marketing with regards to direct communications. Phillis was most concerned with the restoration of trust in government communication, rather than the establishment of marketing principles. It seems that, in this case, the events leading up to Phillis had been used to usher in principles that were somewhat unrelated, using a crisis in government communication structures to bring about a fundamental change to government communication philosophy. 


\section{Locating Engage: New Public Management, Public Choice Theory and the extension of the logic of marketisation to government communication}

This article has to this point addressed the communications structures under the GCN and policies encompassed by the Engage programme. In this next section it will seek to locate the programme in relation to New Labour's wider approach to public administration, under the influence of NPM. In so doing it will be argued that the Engage programme is consistent with the overall New Labour project, and reflects the influence that New Labour had during its time in office over the 'non-political' Civil Service. New Labour substantially adopted the NPM approach to the reform of public services, which can be said to be inclusive of:

various forms of decentralizing management within public services (e.g., the creation of autonomous agencies and devolution of budgets and financial control), increasing use of markets and competition in the provision of public services (e.g., contracting out and other market-type mechanisms), and increasing emphasis on performance, outputs and customer orientation. (Larbi, 1999: iv)

The late Stuart hall, trenchant critic of New Labour, termed NPM 'the marketisation of the state's governing and administrative practices, the transformation of public service individuals into "entrepreneurial subjects" and the adaptation of the machinery of state to the "mission" of "entrepreneurial governance" (Hall, 2003: 16). For Hall (2003: 16), NPM was the path by which "neo-liberal ideas actually inform institutional practices'. In terms of government communication for New Labour, this translated to the dictum: 'More satisfied customers are cheaper to serve and easier to deal with' (Cabinet Office, 2010). But this approach is not alone driven by having easier customers (citizens) to deal with, so that public administration will become more efficient; customer service is rather intrinsic to governance under this model, where 'public organisations have no intrinsic rationale but act under a rationality assumption deriving from the value they create for society' (Lane, 2005: 7).

An underpinning concept of NPM is public choice theory (Denhardt, 2011; Lane, 2005), and it was also influential in the development of New Labour's approach to public administration. Summarising the work of Ostrom, Denhardt (2011: 138) notes that in public choice theory there is a 'methodological individualism, or the presumption that the individual-that is, a representative individual decision maker-is the basic unit of analysis ... self-interested, rational, and seeking to maximize his or her own utilities'. In the case of New Labour, the consumer of public services became central, as the figure who 'stands at the heart of New Labour's approach to the reform and modernisation of public services' (Vidler and Clarke, 2005: 19). Marquand (2004) argues that by adopting public choice theory into the delivery of public services, not all public services necessarily need to be privatized, concurring with Hall (2012: 18), 'New Labour finally understood that there was no need for the political hassle to privatise. You could simply burrow underneath the distinction between state and market'. This can be seen to be encapsulated by the Blairite government minister Alan Milburn, who compared the requirements of public services today with the principles of the 1940s: 'Today we live in a quite different world. We live in a consumer age. People demand services tailor made to their individual needs' (Milburn, 2002, cited in Vidler and Clarke, 2005: 2021). Finlayson's (2009) analysis of schemes such as the Child Trust Fund, that involved individual parents being given responsibility for investing the government payment that they received at the birth of a child, shows how these ideas became actualised in policy. Rather than the 'man-from-the-ministry-knows-best approach to public services' (as 
described by the former Prime Minister Gordon Brown) (Brown, 2010), New Labour entrusted the payment to individuals on the basis that they knew best. New Labour implemented this approach extensively in its approach to healthcare, education (and other sectors), using the consumer as an 'organizing principle' (Vidler and Clarke, 2005: 20). Indeed, for Hall (2003: 16) the adoption of a public choice approach was for New Labour 'the main source of the drive to re-constitute citizens as consumers'.

The central principles of the Engage programme can be clearly understood within the terms of NPM, especially with regards to government directing its communication to the customer, as a consumer-receiver of government communication, rather than as a citizen-receiver. By re-constituting citizens as consumers (cf. Hall, 2003: 16) through its communication, New Labour could imagine the individual in communication terms in a similar way that it had done so in terms of the wider economy and society. The wider public policy agenda of the government became influential on New Labour's reform of the civil service structures. As New Labour moved increasingly further from its democratic socialist roots towards a Thatcherite model of governance, the 'customer as individual' increasingly became the way that citizens were thought of. As the 'new mission for government communication' (returning to James's understanding) becomes one that helps 'Government understand and respond to what people want and need and to help people find what they want and need from Government' (Cabinet Office, 2005: 3), government becomes increasingly unable to speak to wider social, economic and political issues that affect society as a whole, not just the individual. Under the terms of Engage, NPM is thoroughly worked through across the communication apparatuses of government. Counter claims, arguing for a type of government communication that speaks to wider society, have no place under this approach; in Alan Milburn's words, 'We live in a consumer age' (Milburn, 2002, cited in Vidler and Clarke, 2005: 20-21), and thus the place of the citizen in society and their communicative relationship with government is increasingly replaced by that of the consumer.

\section{Conclusions}

In assessing the extent to which these wider political developments had a bearing on government communication, a number of concluding points can be made in light of the case study on the Engage programme. First, the extension of the logic of the market to government communication can be said to have taken place, to the extent that while most government communication was not literally moved into the private sector, private sector principles were appropriated from marketing theory and brought into the centre of government communication. Staying within Hall's terms mentioned above, in so doing 'the distinction between state and market' (Hall, 2012: 18) is undermined. In this sense, extending the logic of the market to government communication under New Labour first entails government changing the approach it takes to its communication, rethinking the way in which it conceives of its target audience. Here, government communication remains within the civil service (the public sector), but it is planned and implemented as though it was in the private sector. Despite this, the latter move to shut down the COI in 2011, recommended by Matt Tee, the second incumbent of the Permanent Secretary, Government Communications post (Cabinet Office, 2011), was a more literal move towards a privatised model for government advertising services, allowing the logic of marketisation to follow its course. Government advertising was taken out of the civil service, and instead replaced with a system that functions to tender advertising work to private sector advertising agencies. Comments from the 
Conservative Cabinet Office minister Francis Maude on the decision are again consistent with the NPM approach, showing continuity from New Labour to the Conservative-Liberal Democrats coalition government: "communications spending in the future will never again get out of hand and instead will be more transparent, better co-ordinated and less bureaucratic' (BBC News, 2011). It must be asked: where are the limits to the extension of market logic in relation to government communication, and indeed, full privatisation? If government is willing to move advertising into the private sector, why not also privatise news management, and have professional public relations agencies handle the news-advertising accounts?

Second, government communication has also become increasingly treated like other areas of government expenditure, as akin to the funding of hospitals or roads, which is further evidence of the influence of NPM on government communication. It can be noted that in 1997 the Cabinet Office (1997: 28) had in place a principle that suggested that government communication 'should be conducted in an economic and appropriate way, having regard to the need to be able to justify the costs as expenditure of public funds', long before Engage was implemented. It follows therefore that government communication to its citizens (or customers) can be cut back as financial pressures necessitate: if you cannot afford to communicate to citizens, cut back the budget. Matt Tee's Review of government direct communication and the role of COI (Cabinet Office, 2011) argues this point precisely, where Tee links the need to reduce government spending on communication with the UK government's priority (post2010) to reduce the fiscal deficit. Under a heading 'A smaller role for government' he argues:

It is ... envisaged that there will be fewer but more effective communications, with a greater role being passed to communities and to partners, both civic and commercial. This means that paid-for communications will not be the only solution to government marketing problems. There may be others who are better placed to achieve its goals. (Cabinet Office, 2011: 30)

This is a precise call for outsourcing the work of government communication, both to the market and to other partners in civil society (who are not described). Thus he asks, 'are there commercial, voluntary or civic sector partners with whom government could work? Such partners may often have a closer relationship with the target audience through existing channels' (Cabinet Office, 2011: 31). In Tee's understanding, government need not claim that it knows best on how it should communicate. This loss of confidence in government's ability to communicate to its citizenry sits squarely within the logic of the NPM approach.

Third, the way government communication was staffed with the establishment of the GCN and the Engage programme became consistent with the wider NPM approach, where "The New Public Management "empowers" civil servants to abandon the principles of political impartiality and, like private-sector CEOs, "take ownership" of their sectors, in a more "agency-driven" style' (Hall, 2003: 17). This can be further explored in light of Marquand's (2004) Decline of the Public thesis, which comprehensively overviews the systemic destruction of this public domain under the marketisation and privatisation of public services, and the spread of the doctrine of neoliberalism. Marquand's (2004: 1) definition of public domain is that space which is 'the domain of citizenship, equity and service whose integrity is essential to democratic governance and social well-being', linked to the notion of the public interest, while its institutions 'are the sources of public trust' (Marquand, 2004: 33). In line with the 
extension of neoliberal principles to the public sector, Marquand argues that the Senior Civil Service in the UK also became transformed, a domain "where the frontiers of the public domain had been most zealously guarded, and in which its values had been most thoroughly internalized' (Marquand, 2004: 2). We see this clearly in the approach of Howell James discussed above, whose approach was perhaps indistinguishable from that of one in charge of communications at a private sector firm. This is directly in line with Hall's idea that New Labour didn't need the political hassle of full privatisation (Hall, 2012: 18); many parts of the civil service that could not be directly privatised were rather handed to next-step agencies, whose 'managers were supposed to operate as though they were running private firms' (Marquand, 2004: 109). Here, the logic of marketisation stands in for full privatisation. For Marquand (2004: 109), the 'rump' that was left over would be subjected to 'subtler methods' that 'could - and did - transform its mentality'. In the case of the Engage programme, we can understand the extension of the logic of the market to government communication, in these terms: the public domain that previously incorporated government communication is increasingly dissolved, allowing government communication to be privatised in some areas in a literal sense, and in other areas is hollowed out by the undermining of the concept of the public domain. 


\section{Notes}

1. James uses the 'lemons into peaches' analogy from economic theory, where lemons are considered dud products, and peaches are considered good products. The seller knows the difference, but the buyer does not. As a result there is a breakdown in trust, and the value of both the lemons and the peaches diminish. In this speech James argues that there is a lesson in this for government communication.

2. Talking to Me? was published by the Cabinet Office in conjunction with private sector consultants Henley Centre/HeadLightVision (part of WPP, the global advertising group) and Media Edge (specialists in market engagement).

3. Phillis mentions the 'customer' in this sense on six occasions, suggesting that online communication be 'customer-driven' (Cabinet Office, 2004: 26) and suggests that an improved regional communications service be 'customer focused and responsive to the public's needs' (Cabinet Office, 2004: 19). In an appendix to the report, early thinking from the review group behind the recommendations did suggest 'It is important to recognise the role of the general public as customers' (Cabinet Office, 2004: 33). However, the resulting 'test' seeks to engender better engagement with the 'public'. It is an emphasis on the public rather than on the customer that is much more in keeping with the overall tenor of the Phillis recommendations when taken as a whole. 


\section{References}

Andrews L. 2006. Spin: From Tactic to Tabloid. Journal of Public Affairs 6: 31-45.

DOI: $10.1002 /$ pa.37

Atkinson P, Coffey A. 2004. Analysing Documentary Realities. In Qualitative research: Theory, method and practice, Silverman, D (ed.). London: Sage; 56-75.

BBC News. 2011. Government ad agency COI to be closed down. http://www.bbc.co.uk/news/uk-politics-13890059. Accessed on 10 June 2013.

Brown G. 2010. Speech on Building Britain's Digital Future - Monday 22 March 2010. http://www.number10.gov.uk/Page22897. Accessed on 15 April 2010.

Cabinet Office. 1997. Guidance on the Work of the Government Information Service, July 1997: Annex 1. In Mountfield Review, Report of the Working Group on the Government Information Service. Cabinet Office: London; pp. 28-34.

Cabinet Office. 2004. An Independent Review of Government Communications: Chairman, Bob Phillis. Cabinet Office: London.

Cabinet Office. 2005. Talking to Me? Connecting with Citizens in the Changing Media Landscape. Cabinet Office: London:

Cabinet Office. 2006a. What is Engage...?

http://web.archive.org/web/20070203164252/engage.comms.gov.uk/what-isengage.html. Accessed 30 July 2010.

Cabinet Office. 2006b. The communication challenge.

http://web.archive.org/web/20070212040531/engage.comms.gov.uk/what-isengage/the-communication-challenge.html. Accessed 10 July 2010.

Cabinet Office. 2006c. Key components.

http://web.archive.org/web/20070212040421/engage.comms.gov.uk/what-isengage/key-components.html. Accessed 10 July 2010.

Cabinet Office. 2007. Making Government work better by ... Putting our audiences first. In Making Government Work Better. Cabinet Office: London; pp.42-43.

Cabinet Office. 2009. Letter from Sir Gus O’Donnell to Francis Maude MP, 14 April 2009. http://image.guardian.co.uk/sys-

files/Politics/documents/2009/04/15/odonnellletter.pdf. Accessed 30 July 2010.

Cabinet Office. 2010. Customer Journey Mapping: An Introduction. Cabinet Office: London.

Cabinet Office. 2011. Review of government direct communication and the role of COI. Cabinet Office: London.

COI. 2010. The Central Office of Information. http://coi.gov.uk/. Accessed 15 August 
2010.

Daintith T. 2001. Spin: A Constitutional and Legal Analysis. European Public Law 7: 593-623.

Denhardt R. 2011. Theories of Public Organization (6th edition). Wadsworth Learning: Boston, MA.

ESOMAR. 2010. Insight Generation: Understanding insight driven innovation. http://www.esomar.org/index.php/insight-generation.html. Accessed 30 July 2010.

Finlayson A. 2009. Financialisation, Financial Literacy and Asset-Based Welfare. The British Journal of Politics and International Relations 11: 400-421.

DOI: 10.1111/j.1467-856X.2009.00378.x

Franklin B. 2004a. A Damascene Conversion? New Labour and Media Relations. In Governing as New Labour: Policy and politics under Blair, Ludlam S and Smith M (eds). Palgrave Macmillan: Basingstoke; 88-105.

Franklin B. 2004b. Packaging Politics: political communications in Britain's media democracy. Arnold: London.

Gaber I. 2000a. Lies, Damn Lies ... and political spin. British Journalism Review 11: 60-70. DOI: 10.1177/095647480001100111

Gaber I. 2000b. Government by spin: an analysis of the process. Media, Culture and Society 22: 507-518. DOI: 10.1177/016344300022004008

Gaber I. 2004. Alastair Campbell, exit stage left: Do the "Phillis" recommendations represent a new chapter in political communications or is it 'business as usual'? Journal of Public Affairs 4: 365-373. DOI: 10.1002/pa.199

GCN. 2013a. Government Communication Professional Competency Framework. London: GCN.

GCN. 2013b. Doing the job - and doing it right.

https://gcn.civilservice.gov.uk/blog/2013/02/04/doing-the-job-and-doing-it-right/.

Accessed 27 February 2014.

Habermas J. 2009. Europe: The Faltering Project. Polity: Cambridge.

Hall S. 2003. New Labour's Double Shuffle. Soundings 24: 10-24.

Hall S. 2012. The Neoliberal Revolution. In The Neoliberal Crisis, Rutherford J and Davison S (eds). Soundings/Lawerence Wishart: London; 8-26.

HM Government. 2007. What is Engage?

http://web.archive.org/web/20071006171515/www.cabinetoffice.gov.uk/government_c ommunication/engage/what_is_engage.aspx. Accessed 10 July 2010. 
HM Government. 2008. New Permanent Secretary, Government Communication. http://www.cabinetoffice.gov.uk/newsroom/news_releases/2008/081112_communicatio n.aspx. Accessed 30 March 2010.

HM Government. 2009. Government response to the HOL Comms Committee. http://www.parliament.uk/documents/upload/GovtCommunications_GovtResponse.doc. Accessed 30 June 2009.

House of Commons, Public Administration Select Committee. 2002. "These Unfortunate Events": Lessons of Recent Events at the Former DTLR (HC 303, Eighth Report of Session 2001-02) - Report, and Proceedings of the Committee. The Stationary Office Limited: London.

House of Lords, Select Committee on Communications. 2009. Government Communications: Report with Evidence (HL7, First Report of Session 2008-09) Report with Evidence. The Stationary Office Limited: London.

James H. 2005a. What future for Government Communications? Speech to a CPPS (Centre for Public Policy Seminars) Seminar. 20 January 2005.

James H. 2005b. Lemons into Peaches. Speech to Royal United Services Institute conference, Managing Information Asymmetry. 15 November 2005.

Lane JE. 2005. Public Administration and Public Management: The principal-agent perspective. Routledge: Abingdon.

Larbi G. 1999. The New Public Management Approach and Crisis States. UNRISD: Geneva.

Marquand D. 2004. Decline of the Public. Polity: Cambridge.

McNair B. 2000. Journalism and democracy: an evaluation of the political public sphere. Routledge: London.

McNair B. 2004. PR Must Die: spin, anti-spin and political public relations in the UK, 1997-2004. Journalism Studies 5: 325-338. DOI: 10.1080/1461670042000246089

Milburn A. 2002. Speech to the Annual Social Services Conference, Cardiff. 16 October 2002. [cited in Vidler and Clarke, 2005]

Vidler E, Clarke J. 2005. Creating Citizen-Consumers: New Labour and the Remaking of Public Services. Public Policy and Administration 20: 19-37.

DOI: $10.1177 / 095207670502000202$

Weir S. 2002. Memorandum by Professor Stuart Weir, Democratic Audit (GI 2). UK Parliament.

http://www.publications.parliament.uk/pa/cm200102/cmselect/cmpubadm/303/2022810 .htm. Accessed 30 June 2010.

Yeung K. 2006. Regulating Government Communications. Cambridge Law Journal 65: 
53-91. DOI: 10.1017/S0008197306007045 